\title{
Ultrastructural Details of the Apparatus of Gliding Motility of Myxococcus fulvus (Myxobacterales)
}

\author{
By HEINRICH LÜNSDORF* AND HANS REICHENBACH \\ $G B F$, Gesellschaft für Biotechnologische Forschung, Mascheroder Weg 1, \\ D-3300 Braunschweig, FRG
}

(Received 18 January 1989; accepted 2 February 1989)

\begin{abstract}
Cell wall preparations of the myxobacterium Myxococcus fulvus were fractionated by ionexchange chromatography. Highly ordered chain-like structures were found in certain fractions when negatively stained specimens were inspected in the transmission electron microscope. The chain-like structures, which we call 'strands', were built up of two structural components: (1) a ring with an outer diameter of 12 to $15 \mathrm{~nm}$ which was regularly stacked with a periodicity of $14 \mathrm{~nm}$, and (2) an elongated component, measuring $11.0 \times 2.8 \mathrm{~nm}$. Each ring appeared to be linked to the next one by two elongated components. Their orientation towards the elongated components was somewhat variable, which suggests a certain flexibility and a potential for conformational changes of the 'strands'. Three or more of the 'strands' appeared to form a superstructure, which is defined as 'ribbon', which might undergo conformational changes leading to the observed shrinkage in the transverse direction of about $40 \%$. We suggest that the structures described create contraction waves in the surface of the myxobacterial cell, and that those waves drag the cell along. The organization of the apparatus of gliding motility in the cell surface could only very rarely be seen. An exceptionally well-preserved whole cell in a negatively stained specimen showed a surface pattern consisting of parallel ridges, indicated by dark stain lines and 40 to $50 \mathrm{~nm}$ wide, running helically around the cell pole. At a higher magnification these parallel ridges showed a distinct, periodic substructure normal to their long axis and with a spacing of $14 \mathrm{~nm}$, which corresponds exactly to the periodicity of the stacked rings within the 'strand'.
\end{abstract}

\section{INTRODUCTION}

Bacteria may translocate on solid surfaces in a number of different ways (Henrichsen, 1972). Apart from the swarming of certain flagellate bacteria, gliding is the most conspicuous technique by which bacteria may spread over a suitable substrate like an agar surface. Gliding motility has aroused much interest in recent years, particularly as it is also of taxonomic importance (Reichenbach, 1981). Gliding organisms are found in at least 7 of the 10 phyla of bacteria presently recognized (Stackebrandt, 1985), although it is not certain whether mechanistically we are always confronted with the same phenomenon. Many hypotheses have been proposed to explain the mechanism of gliding at the molecular level, but so far with little success (for reviews see: Jarosch, 1967; Doetsch \& Hageage, 1968; Burchard, 1981, 1984; Castenholz, 1982). The process may indeed be very complex. Thus, in myxobacteria, gliding motility appears to be controlled by two different sets of genes, one set for social, or S-gliding, which depends on pili (Hodgkin \& Kaiser, 1977; Kaiser, 1979), the other for single-cell adventurous, or A-gliding (Hodgkin \& Kaiser, 1979a,b; Kaiser et al., 1979). Many ultrastructural studies have been done on thin sections, freeze-fractured and negatively stained specimens of various gliding bacteria. Those studies provided remarkably few clues to the mechanism of gliding motility. Apart from certain goblet-shaped elements on the outside of the marine bacterium Flexibacter polymorphus (Ridgeway \& Lewin, 1973) no discrete surface structures have ever been found. 
However, in the periplasmic space of Cytophaga columnaris (formerly Chondrococcus columnaris), directly below the the outer membrane, delicate fibrils with a triangular crosssection were discovered (Pate \& Ordal, 1967). The fibrils, which were only recognizable after careful fixation with glutaraldehyde or formaldehyde, ran parallel to each other at a distance of $16 \mathrm{~nm}$ and formed wide bands which appeared to pass over the cell poles. It was cautiously suggested that these fibrils could be involved in gliding motility. Unfortunately no follow-up studies on the nature of the fibrils appeared. A parallel array of fine fibrils was also found below the outer membrane of several Oscillatoria species, gliding filamentous cyanobacteria (Halfen \& Castenholz, 1971; Halfen, 1973). The Oscillatoria fibrils had a diameter of $5 \mathrm{~nm}$ and were helically wrapped around the cell with a pitch of $60^{\circ}$ in a dense layer. In this case the authors proposed that the fibrils produce contraction waves and indicated in their electron micrographs 'wave-like distortions in the fibril layer' (Halfen, 1973).

In the present article we report on certain macromolecular structures that we isolated from Myxococcus fulvus and that may be part of the gliding machinery. Further, we demonstrate how these structures are arranged in the surface of the myxobacterial cell where they form a unique apparatus of substantial structural complexity.

\section{METHODS}

Myxococcus fulvus strain Mxf 65-9 was grown either in shake flasks or in fermenters on a medium composed of $1 \%(\mathrm{w} / \mathrm{v})$ peptone from casein, tryptically digested (Merck), $0 \cdot 1 \% \mathrm{MgSO}_{4} .7 \mathrm{H}_{2} \mathrm{O} ; \mathrm{pH} 7 \cdot 0$. The cells were harvested in mid- to late-exponential phase by centrifugation at $13000 \mathrm{~g}$ for $10 \mathrm{~min}$. They $(100 \mathrm{~g}$ wet weight) were washed twice with imidazole. $\mathrm{HCl}$ buffer $\left(10 \mathrm{mmol} 1^{-1}, \mathrm{pH} \mathrm{7.5}\right)$ at $4{ }^{\circ} \mathrm{C}$ and resedimented by centrifugation at $10000 \mathrm{~g}$ for $10 \mathrm{~min}$. The washed cells were resuspended in buffer 1 containing, per litre: $3 \mathrm{mmol}$ imidazole. $\mathrm{HCl}, \mathrm{pH} 7.5$; $0.1 \mathrm{mmol} \mathrm{CaCl}{ }_{2} ; 0.5 \mathrm{mmol} \mathrm{Na}{ }_{2} \mathrm{ATP} ; 0.75 \mathrm{mmol} 2$-mercaptoethanol; $1 \mathrm{mmol}$ phenylmethylsulphonyl fluoride; $1 \mathrm{mmol}$ benzamidine. $\mathrm{HCl}$, at a ratio of $2 \mathrm{ml}$ buffer ( $\mathrm{g}$ wet cell mass $)^{-1}$. The suspended cells were disintegrated by one passage through a Sorvall RibiCell press at 6000 to 8000 p.s.i. $(41 \cdot 4-55 \cdot 2 \mathrm{MPa})$ at $5{ }^{\circ} \mathrm{C}$. The homogenate was centrifuged at $100000 \mathrm{~g}$ for $90 \mathrm{~min}$ at $4^{\circ} \mathrm{C}$.

For further purification the supernatant of the cell homogenate was chromatographed on a DEAEcellulose column (DE 52; Whatman), which had been equilibrated with buffer 2 containing, per litre: $10 \mathrm{mmol}$ imidazol. $\mathrm{HCl}$, pH 7.5; $0.1 \mathrm{mmol} \mathrm{CaCl} 2 ; 0.5 \mathrm{mmol} \mathrm{Na}{ }_{2} \mathrm{ATP} ; 0.75 \mathrm{mmol} 2$-mercaptoethanol; $100 \mathrm{mmol} \mathrm{KCl}$. The proteins were eluted at $4^{\circ} \mathrm{C}$ by applying a linear salt gradient from 0.1 to $0.5 \mathrm{~mol} \mathrm{KCl}^{-1}$ in buffer 2 .

Samples of the eluted fractions were negatively stained with $4 \%(\mathrm{w} / \mathrm{v})$ uranyl acetate, $\mathrm{pH} 4.5$ (Valentine $\mathrm{et} \mathrm{al.,}$ 1968), adsorbed to carbon films and picked up with perforated supporting foils (Lünsdorf \& Spiess, 1986). Microscopy was done with a Zeiss EM 10B transmission electron microscope at $80 \mathrm{kV}$ acceleration voltage. Photographs were taken on Agfa Scientia plate film, type 23D56 P3 AH.

\section{RESULTS}

Myxobacteria are able to glide on different kinds of surfaces but are non-motile when freely suspended in a liquid. Samples for study were usually taken from shake flasks or from fermenter cultures. Light microscopy showed that $M$. fulvus cells from liquid cultures were able to glide within $30 \mathrm{~s}$ after they had been placed on an agar-coated slide (data not shown). Thus the machinery of gliding motility is constitutive and present in cells grown in liquid culture.

The supernatant from a disrupted cell suspension was chromatographed on DEAE-cellulose, and negatively contrasted specimens were prepared from samples of different peak fractions. Those fractions that eluted with 120 to $180 \mathrm{mmol} \mathrm{KCl}^{-1}$ contained highly ordered structures which showed remarkable details at the macromolecular level (Fig. 1 $a, b$ ). There appeared to be linear aggregates, which we call 'strands', composed of rings with a highly regular spacing of $14.0 \mathrm{~nm}$ (Fig. $1 a, b$ : large arrowheads). At higher magnification it became apparent that these rings were composed of several globular masses ranging from 3.0 to $3.7 \mathrm{~nm}$ in diameter (Fig. $2 a$, small arrowheads) which most certainly consisted of protein, though this has not yet been verified biochemically. The rings had an outer diameter of 12.6 to $15.6 \mathrm{~nm}$, and an inner diameter of 5.0 to $6.3 \mathrm{~nm}$. They were linked to each other by elongated elements, measuring $2.8 \mathrm{~nm}$ in width and 9.9 to $11.9 \mathrm{~nm}$ in length, and running in two parallel rows.

The regular periodicity within the 'strands' (Fig. la,b) had its origin in the arrangements of 

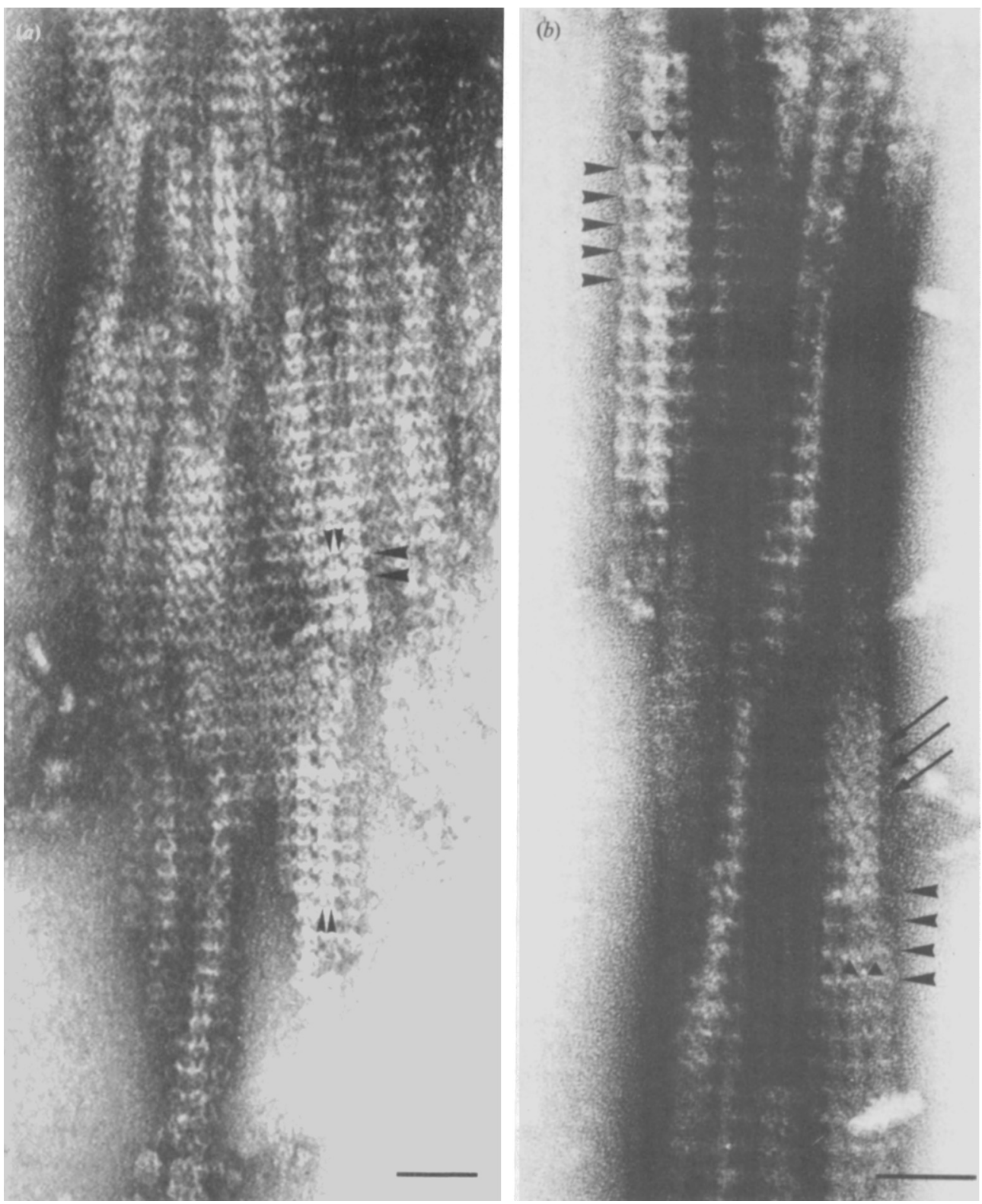

Fig. 1. (a) Isolated aggregates of chain-like 'strands' showing different orientations of periodic structural elements. Rings (large arrowheads) are connected by two rows of elongated elements (small arrowheads). (b) The rings show a highly regular spacing and stand normal to the longitudinal axis of the 'strands' (large arrowheads). Each three 'strands' form a morphological unit, the 'ribbon' (solid triangles). This unit contracts and then shows a herring-bone pattern (arrows). Bars, $50 \mathrm{~nm}$.

the rings which were standing (a) upright on the carbon film and $(b)$ normal to the strand. The conformational state underlying this arrangement obviously is rather stable, for it was retained even in single, small fragments (Fig. $2 f$ ). Further, one could recognize that the elongated elements linked the rings in such a way that the whole system resembled a string of pearls. The two parallel elongated elements may run through the open centre of the rings (Fig. $2 f$ : large arrowheads) and thus be responsible for the linearity of the whole structure. It appears from 

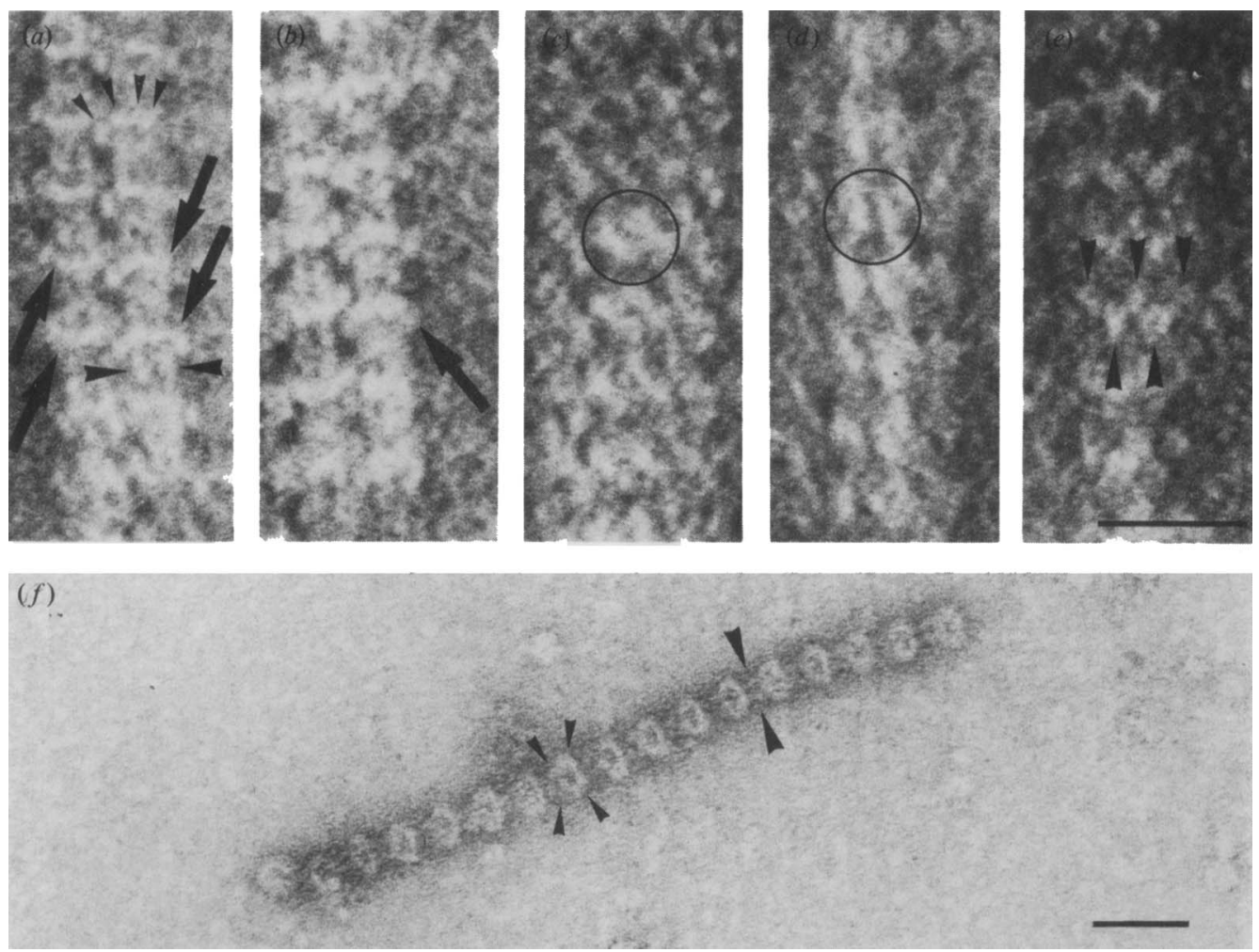

Fig. 2. Details of the structural elements in Fig. 1. $(a, b)$ Rings (solid arrows) normal to the longitudinal axis are connected by two interstitial elongated elements (large arrowheads), which run through the central openings of the rings. The rings are composed of several globular protein masses (small arrowheads). $(c, d)$ Oblique orientation of rings (circled) to the longitudinal axis; $(e) \mathrm{W}$-shaped projection of structural elements normal to the axis (large arrowheads). ( $f$ ) Fragment of a chain-like strand. The rings are composed of subunits (small arrowheads) and linked by central elongated masses (large arrowheads). Bars, $30 \mathrm{~nm}$.

electron micrographs of the isolated material, as well as of the pattern of the cell surface (see below), that 'strands' are connected to form structures of a higher order, which we call 'ribbons'.

It was further possible to distinguish different orientations of the rings relative to the longitudinal axis of the 'strand', i.e. all rings within one strand were oriented normal to the longitudinal axis but in neighbouring strands they showed different angles of incidence (Fig. $2 a$ : solid arrows). Alternatively the rings stood upright but were oriented obliquely to the long axis of the 'strand' to various degrees (Fig. $1 a$, Fig. $2 c, d$ : circles). A gradual change in orientation is shown in Fig. $1(b)$, where within three strands the rings turn from a position perpendicular to the axis (solid triangles and arrowheads) to an oblique one, thus creating a compact herring-bone pattern (arrows). By this change in orientation the original width of the ribbon was reduced by about $40 \%$.

Another pattern was found consisting of small electron-transparent masses which were arranged in such a way that they resembled the letter $\mathrm{W}$, apparently still another conformational state of the superstructure (Fig. $2 e$ : arrowheads).

The longest aggregates isolated by ion-exchange chromatography measured $1.4 \mu \mathrm{m}$; the maximum width was about $0.3 \mu \mathrm{m}$. These aggregates often appeared to be monolayers. Identical structures have also been found in preparations of $M$. xanthus (data not shown).

For electron microscopic studies of exponentially growing bacteria, cells were adsorbed to carbon films (see Methods). Under the conditions used the bacterial cells typically showed a wrinkled cell surface with longitudinal folds (Fig. 3: asterisks) as has been often described for 


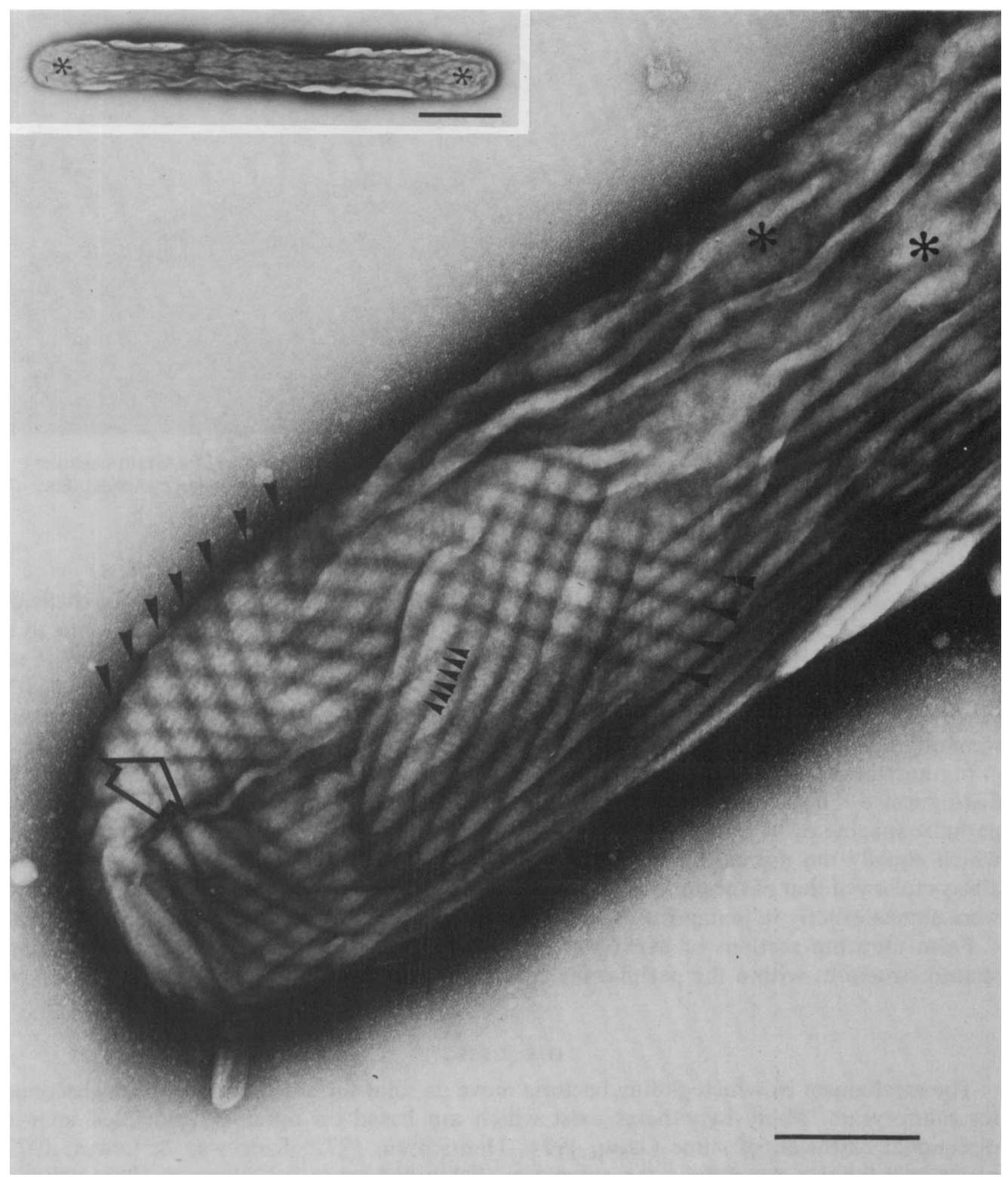

Fig. 3. Negatively stained cell of $M$. fulvus showing a regular helical surface pattern. Large arrowheads indicate dark stain-lines on the cell surface. Small arrowheads mark the fine substructure normal to the orientation of the dark stain lines. Substructures with an oblique orientation are indicated by an open arrow. Asterisks indicate invaginations of the cell surface. Inset: the usual appearance of a negatively stained cell. Bar, $0 \cdot 2 \mu \mathrm{m}$; inset bar, $1 \mu \mathrm{m}$.

various gliding bacteria (Follet \& Webley, 1965). These folds seem to be the consequence of osmotic effects, caused by the high concentration of uranyl acetate solution $(4 \%)$. Cells which were negatively stained with 1.5 to $2 \%$ uranyl acetate solution showed a smooth cell surface and, as a consequence of insufficient contrast, structural details could not be recognized.

Nevertheless it was possible to find cells, although rather rarely, that apparently showed the topographical organization of the gliding machinery, with the structural elements described above. One such cell that was particularly well preserved had a distinctive surface pattern of 


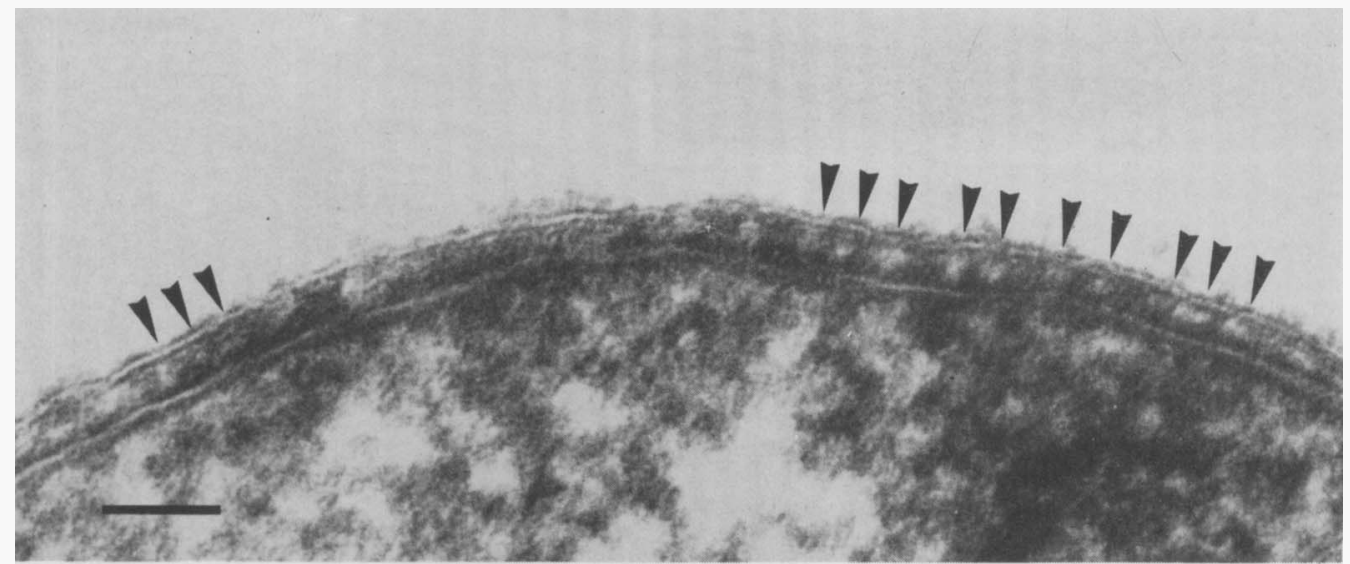

Fig. 4. Ultrathin section of $\mathrm{Mxf} 65-9$. The cell wall shows the typical appearance of a Gram-negative bacterium. Within the periplasmic space regularly aligned structures can be seen (arrowheads). Bar, $50 \mathrm{~nm}$.

dark stain-lines at one of its poles (Fig. 3: solid arrows). These lines ran in parallel and helically around the cell pole. Between them light zones could be distinguished which we assume to be identical with the ribbons as defined above. The latter had a constant width of 40 to $46 \mathrm{~nm}$ which increased slightly to $55 \mathrm{~nm}$ near the edge of the cell and thus corresponds to the dimensions of a ribbon of three to four strands. At the edge of the cell the ribbons could sometimes be seen to protrude like ropes.

In the ribbons in between the dark stain-lines a pattern of much finer lines could be distinguished. These fine lines usually ran perpendicular to broad stain-lines, with a very regular periodic spacing of 14 to $15 \mathrm{~nm}$ (Fig. 3: small arrowheads) and could correspond to the rings which equally run normal to the strands. The topographical orientation of the substructure always followed that of the dark stain-lines. Further, within a band all lines of the substructure were almost exactly in juxtaposition and seemed to be interconnected across its whole width

From ultrathin sections of Mxf 65-9 cells one can recognize the appearance of regularly spaced structures within the periplasmic space (Fig. 4: arrowheads).

\section{DISCUSSION}

The mechanism by which gliding bacteria move on solid surfaces has been under discussion for many years. Many hypotheses exist which are based on different principles such as: directional extrusion of slime (Jahn, 1924; Henrichsen, 1972; Ridgeway \& Lewin, 1973); contractile tubular elements in the cytoplasm (Schmidt-Lorenz \& Kühlwein, 1968; SchmidtLorenz, 1969; Bisalputra et al., 1975; MacRae \& McCurdy, 1975, 1976; Burchard et al., 1977); contraction waves along the cell surface (Gräf, 1965; Pate \& Ordal, 1967; Doetsch \& Hageage, 1968; Halfen \& Castenholz, 1971; Henrichsen, 1972; Halfen, 1973; Humphrey et al., 1979); polar fimbriation (MacRae \& McCurdy, 1976); and excretion of surface-active material (Dworkin et al., 1983; Keller et al., 1983). In addition, at least in myxobacteria, there exists evidence for a considerable genetic complexity of the gliding machinery involving about 40 genes (for a review see Kaiser et al., 1979).

Elaborate hypotheses on the mechanism of gliding motility have been proposed in recent years for Cytophaga johnsonae and Flexibacter columnaris by Pate \& Chang (1979), and for Cytophaga sp. strain U67 by Lapidus \& Berg (1982). Both laboratories studied the translocation of latex spheres on the surface of immobilized cells, and both came to the conclusion that those particles move on definite tracks along the cell surface. With respect to the machinery of gliding motility they came, however, to completely different conclusions. Pate \& Chang (1979) observed 


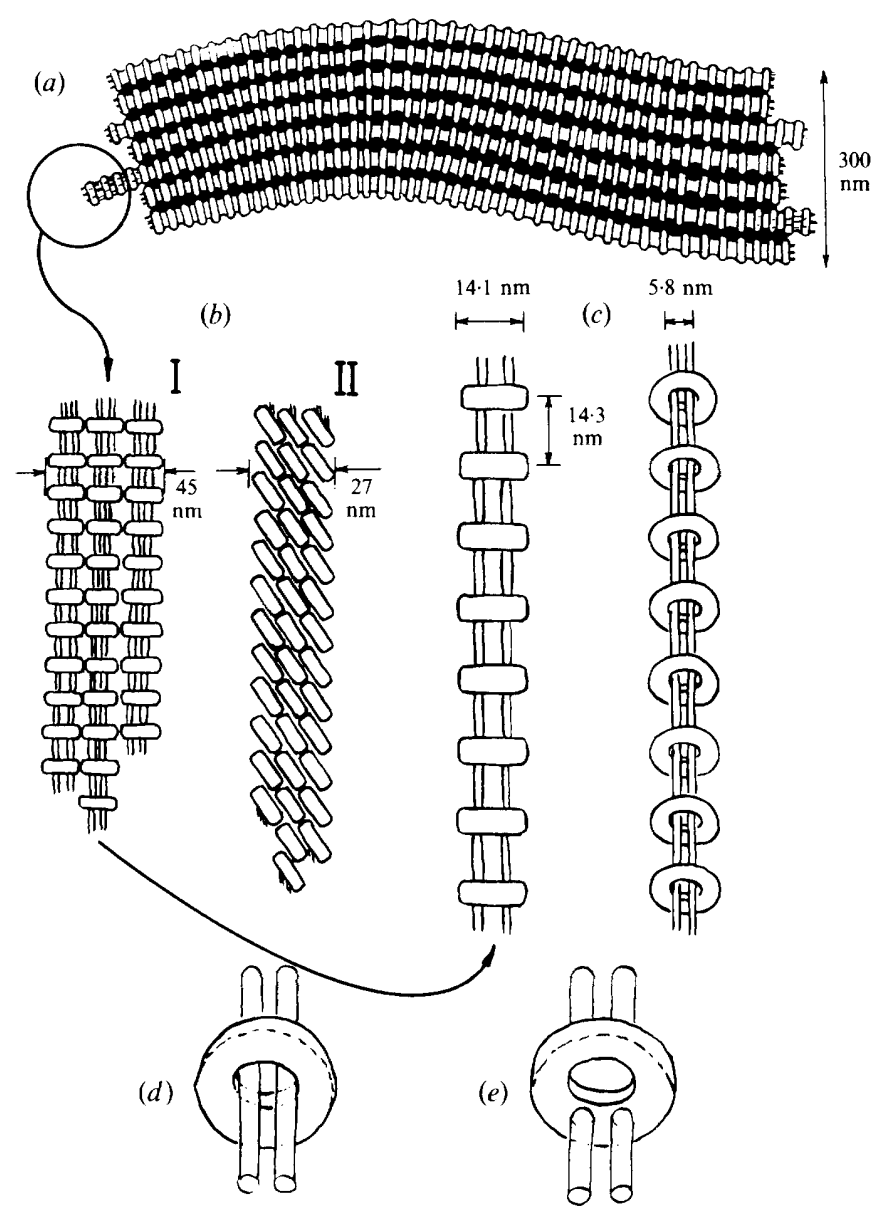

Fig. 5. Nomenclature and interpretation of the observed structures. (a) A belt, consisting of seven ribbons. The depressions between the ribbons are filled with dark stain. The belt appears to be helically wrapped around the cell. (b) A ribbon consisting of three strands (see also circle in $a$ ). The ribbon exists in two states: I, expanded and II, contracted. The contraction results in a shrinkage of the width of the ribbon. $(c)$ A strand composed of rings which are connected by two elongated elements. The ring structure becomes apparent only when they are tilted. There exist two possible arrangements between rings and elongated elements : either $(d)$ the elongated elements are long continuous filaments passing through the openings of the rings, or $(e)$ they are short bolts fastened to the rings. The remarkable stability of the strands may suggest the former type of connection.

ring-like particles in the electron microscope which they obtained from cell lysates. They interpreted these structures as the morphological counterparts of the rotary discs of the basal region of bacterial flagella and postulated that gliding motility is due to the rotation in the plane of the cell surface of such ring-like particles which cover the whole cell. No evidence for such a rotation of those rings was, however, given. The rotation of the ring-like structures would then also explain the various movements of the adsorbed latex spheres (Pate \& Chang, 1979; Pate, 1985).

In contrast, Lapidus \& Berg (1982) proposed that the latex spheres are bound to specific binding sites in the outer membrane of the cell and that those sites move along distinct tracks. Interacting protein complexes in both the outer membrane and the peptidoglycan layer may create the required motive force by making and breaking bonds between them (Humphrey et al., 1979; Duxburry et al., 1980).

The data presented in this work fit the model of Lapidus \& Berg (1982) in so far as we see a 
linear pattern with a unique ultrastructure in the cell surface of our strain M. fulvus Mxf 65-9. After chromatography of broken cells we find equivalent superstructures which are composed of linear chain-like strands. We suggest that this pattern is related to the machinery of gliding motility and seems to reflect a real topographical structure. It is not due to a stain artefact within the periplasmic space that could arise if the outer membrane had been damaged and thus would allow the stain to penetrate.

Thus the gliding apparatus of Myxococcus could consist of a band that is helically wrapped around the cell and situated underneath the outer membrane (an interpretation of our observations is summarized in Fig. 5) During gliding the belt could cause a slight corrugation in the outer cell surface, and as this corrugation travels over the cell the latter is propelled. The link between the topographical structures just described and the underlying apparatus is to be seen in the linear chain-like strands and their aggregates. That the strands really are a part of the apparatus seen in the cell surface is concluded from the following observations. Firstly, there is an agreement in the spacing of the transverse periodicities of the isolated chain-like structures $(14.3 \mathrm{~nm}$; Fig. $1 b$ : large arrowheads) and that of the fine substructures of the cell surface (14 to $15 \mathrm{~nm}$; Fig. 3: small arrowheads). Secondly, the oblique orientation of the fine substructures between the dark stain-lines of the surface pattern (Fig. 3: open arrow) corresponds exactly to the oblique orientation of the rings of the chain-like aggregates (Fig. $2 c$ and $d$ ). Thirdly, the space between the broad dark stain-lines on the cell surface spans 40 to $46 \mathrm{~nm}$, which fits the observation that often three chain-like strands equally spanning 45 to $50 \mathrm{~nm}$ in width are combined to interact. This interaction leads to a condensation in the transverse direction of the aggregate of the chain-like strands, or ribbons, to form a herring-bone pattern (Fig. 1 $b$ : solid triangles, arrows). A fourth correspondence is found in ultrathin sections of cells grown on agar plates. Here one can recognize structural elements within the periplasmic space underneath the outer membrane which are periodically arranged and which alternate with regions without such a substructure (Fig. 4).

It was not possible to detect structural features corresponding to the chain-like strands in freeze-fractured specimens. Rather here the periplasmic space is filled with homogeneous material of a perfectly smooth appearance, probably burying and obscuring the abovementioned aggregates (data not shown). These observations are in agreement with those made by Schmidt-Lorenz \& Kühlwein (1969) on myxobacteria, and by Follet \& Webley (1965) on Cytophaga, who both suggest that the periplasmic space is filled with slime material.

Some comments are in order on the surprising diversity in the arrangement of the structural elements in the isolated aggregates because here the key to the understanding of gliding motility may be hidden. While the preparation artefacts that may interfere with these structures are not known, one may still conclude that the basic ultrastructural elements are more or less in their native state. At least two structural components are involved, viz. (1) rings and (2) interstitial elongated elements. The linkage between these two structural elements appears to be rather flexible. It allows the rings to switch from a perpendicular to an oblique orientation and further to tilt towards the supporting carbon film. The conformational change in the ribbon (Fig. $1 \mathrm{~b}$ ) could well be the decisive step in gliding motility as it may lead to a contraction of the ribbon by $40 \%$ in width. Conceivably such conformational changes could result in the migrating folds proposed above. The morphological complexity of the apparatus seen in the electron microscope would be in excellent agreement with the genetic complexity of gliding motility mentioned above (Kaiser et al., 1979).

Although we can correlate certain isolated linear aggregates to morphological structures of the cell surface from the gliding bacterium $M$. fulvus, and may thus have a first glimpse of the structural organization of the gliding apparatus, we are of course still far from a full explanation of the mechanism of gliding motility. The exact topography of the belt and the biochemical composition of its elements have next to be elucidated, and the transfer of energy to the gliding machinery remains to be explained. 


\section{REFERENCES}

Bisalputra, T., OAkley, B. R., Walker, D. C. \& SHIELDS, C. M. (1975). Microtubular complexes in blue-green algae. Protoplasma 86, 19-28.

BURCHARD, R. P. (1981). Gliding motility of procaryotes: ultrastructure, physiology and genetics. $A n-$ nual Review of Microbiology 35, 497-529.

Burchard, R. P. (1984). Gliding motility and taxes. In Myxobacteria: Development and Cell Interactions, $\mathrm{pp}$. 139-161. Edited by E. Rosenberg. Berlin: Springer Verlag.

Burchard, A. C., Burchard, R. P. \& Kloetzel, J. A. (1977). Intracellular, periodic structures in the gliding bacterium Myxococcus xanthus. Journal of Bacteriology 132, 666-672.

Castenholz, R. W. (1982). Motility and taxes. In The Biology of Cyanobacteria, pp. 413-439. Edited by N. G. Carr \& B. A. Whitton. Oxford: Blackwell Scientific Publications.

Doetsch, R. N. \& Hageage, G. J. (1968). Motility in procaryotic organisms: problems, points of view, and perspectives. Biological Reviews 43, 317-362.

Duxburry, T., Humphrey, B. A. \& Marshall, K. C. (1980). Continuous observations of bacterial gliding motility in a dialysis microchamber: the effects of inhibitors. Archives of Microbiology 124, 169-175.

Dworkin, M., Keller, K. H. \& Weisberg, D. (1983). Experimental observations consistent with a surface tension model of gliding motility of Myxococcus xanthus. Journal of Bacteriology 155, 1367-1371.

Follett, E. A. C. \& Webley, D. M. (1965). An electron microscopic study of the cell surface of Cytophaga johnsonii and some observations on related organisms. Antonie van Leeuwenhoek 31, 361382.

GRÄF, W. (1965). Bewegungsorganellen bei Myxobakterien. Archiv für Hygiene und Bakteriologie 149, 518526.

HALFEN, L. N. (1973). Gliding motility of Oscillatoria: ultrastructural and chemical characterization of the fibrillar layer. Journal of Phycology 9, 248-253.

Halfen, L. N. \& Castenholz, R. W. (1971). Gliding motility in the blue-green alga Oscillatoria princeps. Journal of Phycology 7, 133-145.

HENRICHSEN, J. (1972). Bacterial surface translocation: a survey and a classification. Bacteriological Reviews 36, 478-503.

HodGkin, J. \& KaISER, D. (1977). Cell-to-cell stimulation of movement in nonmotile mutants of $M$ yxococcus. Proceedings of the National Academy of Sciences of the United States of America 74, 2938-2942.

HodGKIN, J. \& KAISER, D. (1979a). Genetics of gliding motility in Myxococcus xanthus (Myxobacterales): genes controlling movements of single cells. Molecular and General Genetics 171, 167-176.

HODGKIN, J. \& KAISER, D. (1979b). Genetics of gliding motility in Myxococcus xanthus (Myxobacterales): two gene systems control movement. Molecular and General Genetics 171, 177-191.

Humphrey, B. A., Dickson, M. R. \& Marshall, K. C. (1979). Physicochemical and in situ observations on the adhesion of gliding bacteria to surfaces. Archives of Microbiology 120, 231-238.

JAHN, E. (1924). Beiträge zur botanischen Protistologie. 1. Die Polyangiden. Leipzig: Gebr. Borntraeger.
JAROSCH, R. (1967). Studien zur Bewegungsmechanik der Bakterien und Spirochäten des Hochmoores. Österreichische botanische Zeitschrift 114, 256-306.

KAISER, D. (1979). Social gliding is correlated with the presence of pili in Myxococcus xanthus. Proceedings of the National Academy of Sciences of the United States of Amercia 76, 5952-5956.

Kaiser, D., Manoil, C. \& DWorkin, M. (1979). Myxobacteria: cell interactions, genetics and development. Annual Review of Microbiology 33, 595-639.

Keller, K. H., Grady, M. \& Dworkin, M. (1983). Surface tension gradients: feasible model for gliding motility of Myxococcus xanthus. Journal of Bacteriology 155, 1358-1366.

LAPIDUS, I. R. \& BERG, H. C. (1982). Gliding motility of Cytophaga spec. strain U67. Journal of Bacteriology 151, 383-398.

LÜNSDORF, H. \& SPIESS, E. (1986). A rapid method of preparing perforated supporting foils for the thin carbon films used in high resolution transmission electron microscopy. Journal of Microscopy 144, 211 213.

MACRAE, T. H. \& MCCURDY, H. D. (1975). Ultrastructural studies of Chondromyces crocatus vegetative cells. Canadian Journal of Microbiology 21, 18151826.

MACRAE, T. H. \& MCCURdy, H. D. (1976). Evidence for motility-related fimbriae in the gliding microorganism Myxococcus xanthus. Canadian Journal of Microbiology 22, 1589-1593.

PATE, J. L. (1985). Gliding motility in Cytophaga. Microbiological Sciences 2, 289-295.

Pate, J. L. \& Chang, L. Y. E. (1979). Evidence that gliding motility in procaryotic cells is driven by rotary assemblies in the cell envelopes. Current Microbiology 2, 59-64.

PaTe, J. L. \& ORDal, E. J. (1967). The fine structure of Chondrococcus columnaris. III. The surface layers of Chondrococcus columnaris. Journal of Cell Biology 35, $37-51$.

ReICHENBaCH, H. (1981). Taxonomy of the gliding bacteria. Annual Review of Microbiology 35, 339-364.

Ridgeway, H. F. \& LewIN, R. A. (1973). Globletshaped subunits from the wall of a marine gliding microbe. Journal of General Microbiology 79, 119128.

SCHMIDT-Lorenz, W. (1969). The fine structure of the swarm cells of myxobacteria. Journal of Applied Bacteriology 32, 22-23.

SCHMIDT-LORENZ, W. \& KÜHLWEIN, H. (1968). Intracelluläre Bewegungsorganellen der Myxobakterien. Archiv für Mikrobiologie 60, 95-98.

Schmidt-Lorenz, W. \& KüHLWein, H. (1969). Beiträge zur Kenntnis der Myxobakterienzelle. 2. Mitteilung. Oberfächenstrukturen der Schwarmzellen. Archiv für Microbiologie 68, 405-426.

STACKEBRandT, E. (1985). Phylogeny and phylogenetic classification of prokaryotes. In Evolution of Prokaryotes (FEMS Symposium 29), pp. 309-334. Edited by K. H. Schleifer \& E. Stackebrandt. London: Academic Press.

Valentine, R. C., Shapiro, B. M. \& Stadtman, E. R. (1968). Regulation of glutamine synthetase; XII. Electron microscopy of the enzyme from Escherichia coli. Biochemistry 7, 2143-2152. 